\title{
El HOMBRE DE MONTSERRAT: WRITINGS ON VIOLENCE IN THE LATIN AMERICAN CRIME FICTION
}

EL HOMBRE DE MONTSERRAT: ESCRITAS DA VIOLÊNCIA

NA FICÇÃO POLICIAL LATINO-AMERICANA

Víctor Manuel Sanchis Amat

Universidad de Alicante

Alicante, Espanha

\section{Resumen}

El artículo aborda el estudio de la novela adscrita al género policial El hombre de Montserrat, del escritor guatemalteco Dante Liano, como modelo precursor de una forma de narrar que consagró una vía de reescritura de la historia de la violencia de los países centroamericanos de exitosa recepción, tanto novelesca como teórica, que ha convertido la novela en un referente ineludible de la literatura centroamericana de los años 90. Una narrativa, la de Dante Liano, repleta de mecanismos que habían recorrido lo mejor de la narrativa latinoamericana anterior, alejada de los grandes discursos y caracterizada por la hibridez genérica, la transgresión paródica o el localismo léxico. El artículo analiza el entrecruzamiento de géneros y la subversión de la trama, los personajes y reescritura de la historia frente a los postulados clásicos del género policial.

Palabras claves: Dante Liano, El hombre de Montserrat, novela policial, violencia, parodia.

\begin{abstract}
The article adresses the novel El hombre de Montserrat, written by the Guatemalan writer Dante Liano and recognized within the genre of crime fiction, as a precursory model for a narrative that established a way of rewriting the history of violence in Central American countries in both fictional and theoretical terms. Dante Liano's successful reception has turned the novel into a reference of the Central American literature of the nineties. This is due to the fact that his narrative is replete with mechanisms that were seen in the best works of the previous Latin American narrative, far from the great discourses, by a displaying genre hybridization, a parodic transgression or lexical localism.
\end{abstract}

\section{Resumo}

$\mathrm{O}$ artigo aborda o romance El hombre de Montserrat, escrito pelo escritor guatemalteco Dante Liano e atribuído à ficção criminal como modelo precursor de uma narrativa que estabeleceu uma maneira de reescrever a história da violência nos países centro-americanos. A recepção da narrativa de Dante Liano transformou o romance em uma referência inescapável da literatura centro-americana dos anos noventa, e sua narrativa está repleta de mecanismos que cobriram o melhor da narrativa latinoamericana anterior, longe dos grandes discursos, e é caracterizado por uma hibridização de gênero, uma transgressão paródica ou localismo lexical. $\mathrm{O}$ artigo 
This article analyses the interweaving of genres and the subversion of the plot, the characters and the rewriting of the history against the postulates of the classic detective novel.

Keywords: Dante Liano, El hombre de Montserrat, crime fiction, violence, parody. analisa o entrelaçamento de gêneros e a subversáo da trama, os personagens e a reescrita da história contra os postulados da novela clássica de detetive.

Palavras-chave: Dante Liano, El hombre de Montserrat, novela policial, violência, paródia.

El Hombre de Montserrat (Mexico, 1994) is one of the most important works from the new Latin American detective stories during the last decades. This novel by Dante Liano started a prolific narrative movement among the 'isthmus writers' which is characterised by the rewriting of the troubled history (the troubled history rewriting) of the Central American countries. The perpetuation of civil wars in countries such as Guatemala has turned violence into an essential topic of artistic representation.

In this way, the contemporary literature has become a crucial means for revising recent history. The Latin American narrative has evolved considerably over the last decades, from the 70's and 80's Testimonial novel to the roman fusion (JUAN, 2004, p. 89-90) from the 90's. During this decade, the crime novel was able to reexamine the narrative about violence from a different perspective, which has been more attractive for the reader because in it the conflict is assimilated ironically and naturally (MACKENBACH \& ORTIZ, 2008 , p. 82). However, while the crime novels of this decade preserve the North American detective genre tradition, they also remark social criticism.

The initial conceptions of the genre in the Latin American literature appeared with the works of Borges and Bioy Casares ${ }^{1}$ by the middle of the century. They created a character, Isidro Parodi, who solved cases from jail, based on the classic deductive model so called 'whodunit' or mystery novel, typical of Poe's and Conan Doyle's foundational stories. Nevertheless, the new Latin American crime novels from the last years of the 20th century are defined by the imbrication of the mystery solving and the cruel political conflicts in Central American republics.

Inevitably, revolutions, counter-revolutions, civil wars and ferocious dictatorships have modulated the unusual narrative definitions regarding the literary creation from each region and author, and they have had a substantial influence on the invention of new protagonists. These characters are now closer to the models of the well-known detectives Philip Marlowe and Carvalho.

1 From Borges and Bioy Casares to Padura, the Latin American crime novelists have been at the same time theoreticians of the genre, providing a critical identity and introducing it into the cultivated literature. (For a historiographical review of the neopolicial, see NOGUEROL, 2006; MARTÍN \& SÁNCHEZ, 2007). 
A clear example of this assimilation are Leonardo Padura's novels, in which the main character is a police officer, Mario Conde, who faces La Habana's underworld. Pasado Perfecto (1991) and Vientos de cuaresma (1994) were published when Dante Liano was writing El hombre de Montserrat (1994) and El misterio de San Andrés (1996) (MARTÍN y SÁNCHEZ, 2007, p. 49-53).

Mercedes Elena Seoane highlights the close connection between the crime fiction and the social circumstances within its contexts of production. This adaptation to the different representations of violence explains the genre's success among the last Latin American writers. The detective genre was employed to denounce social and political corruption in places where poverty, violence, and impunity are consequences of state repression throughout the 20th century:

Si la emergencia, florecimiento u olvido de ciertos géneros literarios se relaciona y dialoga de distintas formas con el contexto histórico de aparición, no hay duda de que el policial sirve más que bien a la representación ficcional de los hechos criminales cometidos bajo las dictaduras latinoamericanas de los ańos setenta y ochenta, la represión estatal y la(s) guerra(s) y, ya en los noventa, a la tematización de la desintegración, marginalidad y violencia social que son característicos del impiadoso fin de milenio. (SEOANE, 2014).

In this context, the neopolicial has turned into a productive genre to represent new literary modulations of violence. Thus, the genre, plot, characters, and the rewriting of history in the neopolicial from the 90's opposes the strategies undertaken by previous literary works to rationalize violence.

Therefore, the most recent writers of the Central American isthmus have had to develop new narrative strategies in order to face an autochthonous problem, diferent from that of other contexts where the policial has been successful. After decades of civil war, the writers use a distant narrative voice that embraces the grotesqueness of events. The difficult acknowledgment of immeasurable history has developed comical behaviours and characters, and the new novel focuses on them in order to represent conflicts.

Hereafter, this article reviews some terms that have had a critical repercussion for a methodological study about the Central American writers' works, such as Horacio Castellanos Moya (ORTIZ, 2007a; ORTIZ, 2007b; JASTRZĘBSKA, 2011) or Dante Liano. We will adopt these arguments in order to complete a theoretical framework for the study of El Hombre de Montserrat, one of the vanguard novels of the Central American "neopolicial"2.

2 Emiliano Coello (2008) says that Castigo Divino, published by Sergio Ramírez in 1988 and El Hombre de Montserrat, in 1994, were the forerunners of the genre between the writers of the Isthmus. In these novels, we can trace the fundamental features of the genre that will be developed by later writers. 
Dante Liano (1997) coined the notion of "oblique violence" to exemplify a perspective that post-war Central American writers had used to represent violence. From this point of view, the narrator does not focuses on the major characters and the central episodes, but on how the violence of the great historical events affects marginal characters: "Una violencia figurada, que se revela indirectamente en el día a día de los personajes" (LAORDEN, 2015, p. 157). El Hombre de Montserrat depicts violence through the intimacy of Lieutenant García, an irrelevant military who faces some of the bloodiest episodes of the war.

The personalisation of the history also defines the "aesthetics of violence" that Anabella Acevedo Leal (2001) proposed to study post-war literature. The author emphasizes: "aproximarse a esta representación a través de los signos que hablan de la fragmentación de la identidad-colectiva pero principalmente individual-y de la desesperanza" (ACEVEDO in ORTIZ, 2008, p. 87). By the end of the 90's, the endemic violence was progressively losing its ideological arguments to become a daily presence that affected not only the power structures, but also the individual conscience of a society that was facing the failure of decades of conflict. The paradigm shift in the society of the 90's is shown in the disenchantment and despair that Lieutenant Garcia shows in his philosophical comments.

As mentioned before, the narrative voice of the narrators of the Isthmus adopted the ironic distancing and parody to re-read history. Beatriz Cortez (2000) reflected on the post-war anarchy and the fragmentation of society as a collective entity, caused by the failure of conflict, and coined the concept "aesthetics of cynicism" to study the latest Central American narrative.

Cynicism will become an essential narrative strategy in the context of production, immediately following the armed conflict that was already anticipated by Dante Liano's novel:

La posguerra, en cambio, trae consigo un espíritu de cinismo. En consecuencia, esta ficción retrata a las sociedades centroamericanas en estado de caos, corrupción y violencia (...). A pesar de ello, el cinismo, como proyecto estético, no es del todo negativo. De hecho, proporciona una estrategia de sobrevivencia para el individuo en un contexto social minado por el legado de la violencia de la guerra y por la pérdida de una forma concreta de liderazgo. (CORTEZ, 2000, p. 2). 
El Hombre de Montserrat was published in the last period of the Guatemalan military conflict (it was printed for the first time in Italian in 1990). The story created a way into the re-writing of the history of violence in the Central American countries with a successful reception, both fictional and theoretical (see BARRIENTOS, 2003; ACEITUNO, 2005; GRINBERG, 2009).

The new crime novel by Dante Liano presents a confluence of genres that is often found in the narrative of the end of the millennium. The Guatemalan writer has mastered this genre with resounding success in novels such as El Hombre de Montserrat (1994) or El Misterio de San Andrés (1996). These stories modify significantly the gist of the genre that was synthesized by Todorov (1992) in his well-known work Tipologías de la Novela Policial. El Hombre de Montserrat subverts the traditional consideration of the plot and the core characters in a story based on a parodic transgression that is typical in postwar writers. On the other hand, the strategies related to parody and the grotesque articulates, as we shall see, new narrative mechanisms for the revision of recent history and the fictional representation of violence.

Dante Liano reflects some preeminent narrative features in El Hombre de Montserrat that since the decade of the 60's had been improved not only in the crime fiction, but also in other related genres, such as the new historical novel. Humour, irony or cynicism are undoubtedly highlighted as the narrative strategies of the story. The narrative proposal of El Hombre de Montserrat is supported throughout the story in a demystifying parody structure (TOLEDO, 2002), which becomes a decisive transgressive element in both the design of the plot and the antihero, and in the appreciation of the demystification of the official history. These facts change the central concept that had sustained the evolution of the genre throughout the $20^{\text {th }}$ century.

In this context, parody allows for the distancing of the narrator (and the reader) from a reality of excessive violence, which behind the disguise of caricature shows the miseries of the recreated time. As was mentioned before, this is a typical attitude of the Central American writers of the 90's and the first decade of the $21^{\text {st }}$ century who take distance from the conflict by means of caricature as a disfiguring element of violence (RAMÍREZ, MARTÍNEZ, HURTADO and MELCHOR, 2017).

Elzbieta Sklodowska (1991) dedicates an interesting chapter to the analysis of parody in crime fiction in her essay La Parodia en la Nueva Novela Hispanoamericana (1960-1985). In this work, she shows the close link between the evolution of this genre and other contemporary narrative formulae, while also justifying the appropiation of satire by Latin American authors. 
Regarding the literature of the 70's, she states:

no debe considerarse exclusivamente como un distanciamiento (auto)crítico frente al acto de escribir-actitud heredada de los auto-reflexivos ańos 60- sino también como producto de un distanciamiento de la narrativa hermética de las 'superestrellas' del boom. (SKLODOWSKA, 1991, p. 118).

On the one hand, the parodic transgression of this new narrative questions the classical definition of genre and the strategies the new detective genre (see TOLEDO, 2002 or MACKENBACH and ORTIZ, 2008), as some authors like Osvaldo Soriano (Triste, Solitario y Final) or Jorge Ibargüengoitia (Las Muertas) did before the 90's. On the other hand, parody desmystifies events from the intimacy of Lieutenant García, who is not at the center of the conflict but suffers the consequences of the violence it generates.

\section{Towards a Hybridity of Genre}

Against the classic models of the crime fiction enunciated by Todorov (1992) (whodunit, thriller and suspense), Mercedes Elena Seoane (2014) recovers an idea that I consider essential to the understanding of this type of stories about the hibridity of the narrative genre of the Latin American detective novel of the last decades. Since the 70's, detective novels were consolidated in the Latin American canon along with the new historical novel, the testimonial novel and the political novel. The convergence of genres or roman fusion is originated when the weight of historical facts overlaps themes and plots. In this case, the Guatemalan society faces decades of cruel confrontations: "En muchos casos, esta hibridez responde precisamente a la intención de denuncia o de memoria histórica que surge cuando la novela política y el género policiaco cruzan sus caminos". (SEOANE, 2014).

Dante Liano's story is closed with several narrative genres traceable in the tradition, such as the political thriller, the historical novel or even the novel of the jungle, which in the final episode emerges when Lieutenant García is destined on the ground as consideration in favor of saving his brother-in-law from murder charges.

El Hombre de Montserrat develops one of the main modulations of the Latin American crime fiction of recent decades, representing the city as the protagonist of the narrative. Authors like Castellanos Moya continue the tradition of the horrible city, so characteristic of an important part of the Latin American narrative of the end of the millennium (VALERO, 2000). Nevertheless, this novel does not insist on the description of spaces that build the city of Guatemala as locus terribilis (JASTRZĘBSKA, 2011, p. 323). This 
is evidenced by the places where the action is developed: Lieutenant García's workplace (where the main story is set) and the privacy of his home (including descriptions of his anodyne relationship with his wife).

The interpolations between both spaces generate the actions of the story (his brother-in-law is pointed out as the murderer of the man from the Montserrat). Although in El Hombre de Montserrat action predominates over description, the city is represented in his continuous journeys back home from work. The narrator listens to the voices of the city throughout García's trips in his own car, dreams or moments of reflection before sleeping. This is a city that feels dangerous, chaotic and violent that the story does not describe directly and that the characters have assumed as natural (remember the notion of "oblique violence" coined by Dante Liano):

A lo lejos, en la ciudad, una sirena se fue desenrollando. “¿Quién será el desgraciado?”, pensó. Casi enseguida, oyó el desgranarse de unas ametralladoras. Otros respondían al fuego. Oyó un retumbo y reconoció el sonido de la granada de mano. Después, otra. Luego, el fuego cruzado de las ametralladoras. Dos, tres bombazos. Inmediatamente, el silencio. Pocos tiros aislados. "Se acabó la escaramuza”, pensó.

Una punzada le atacó el ojo derecho. El gallo de los vecinos cantó a destiempo. Oyó, mucho más lejos, otro tiroteo. De nuevo, una sirena rasgó el aire. Se acordó de la época en que todos esos ruidos despertaban a su mujer y no la dejaban dormir. Ahora sólo la asustaban los temblores. (LIANO, 2005, p. 35).

On the other hand, the novel explores the jungle narrative strategies. Lieutenant Garcías brother-in-law, Tono, was going to be judged for a murder that he had not committed. So, García gets permission from his superiors to carry him to the border with Mexico in exchange for his own transfer on the battlefield in the jungle. Then, the story focuses on the other side of the war in Guatemala, where the army and the guerrillas kept a bloody dispute away from the noise of the city's media. There, the brutality of the military repression against the guerrillas and indigenous peoples was justified as an act of war by the executioners. Meanwhile, the jungle is represented in the story in two different moments with opposite connotations in the mood of the protagonists. On the first trip by García, the jungle symbolizes an area of freedom, a locus amoenus before the Mexican border, where he has to leave his brother-in-law:

Desde la salida de la capital, habían estado subiendo por las montańas que llevan al occidente. Había fresco, pero no frío. Por las ventanillas abiertas entraba el espeso olor de las pinadas. Después de pasar San Lucas, entraron 
a las rectas llenas de bosques oscuros de Chimaltenango. Curvas y rectas, pero ya no en subida. Y en la planicie del Tejar, campos llenos de maizales, aguacatales, o de puro bosque, se extendían hasta rematar en las lejanas faldas del Acatenango, que, desde ese punto, se adelantaba, en la visión, al volcán de Fuego y al de Agua. "Es como para estacionar a la orilla de la carretera y tirarse entre la hierba a dormir”, pensó García. (LIANO, 2005, p. 88).

In Chapter 5, however, when the Lieutenant is appointed to fight the guerrilla, the space of nature becomes a true descent into hell as the story focuses on the war and the difficulties that the protagonists live. At this point, in an ironic tone Liano plays with the clichés of the novel of the jungle by recreating an episode in which the force of nature seems to detroy the human presence. In a moment of rest, the kaibiles ${ }^{3}$ face the furious attack of ants that devastated everything in their path. In a tragicomic scene, the soldiers draw a circle of protection with their urine to avoid being devoured by those ants:

Ni muy grandes eran. Por lo menos, no como las tambochas. Eran entre hormigas y zompopos. Pero, eso sí, millones. Miles de hormigas todas juntas que se convertían en una sábana negra. Donde pasaban, dejaban todo pelón. Flores, árboles, plantas grandes y chicas, todo se lo hartaban. Y, si, por caso, algún animal les quedaba en el camino, ya que estuviera muerto o enfermo, dejaban sólo el hueso mondo. No había árbol alto ni agujero profundo adonde no llegaran.

Primero se oía un temblor. Era la estampida de los animales que iban huyendo de la marea negra. Al Teniente García el ruido le hacía recordar las matinales de los domingos. Cuando, al final de la película, el héroe iba alcanzando al bandido, todos los niños somataban los pies y no se podía oír el ruido que armaban. Un como terremoto que se acercaba, el tenso rumor creciente de la catástrofe.

(...) García juntó a la tropa en un espacio reducido.

-Déme los puntos cardinales exactos -ordenó el subteniente. Éste tomó la brújula. Brujería, era, en cambio, la operación. Una vez indicados norte, sur, este y oeste, García colocó un soldado en cada sitio. Luego, ordenó:

-Échense una buena meada. (LIANO, 2005, p. 95-96).

After the irony of this scene, Lieutenant García and his soldiers enunciate the military brutality in an indigenous village that, according to the information they had, had given shelter to the guerrillas. After telling the tortures and interrogations that the villagers had suffered, the narrator naturalises the bloody repression with the evasiveness of the protagonist, thus turning the exceptionality of the killing into a routinary event that is justified

3 Kaibiles are elite soldiers of the Guatemalan Army, prepared to carry out special and intelligence operations. 
by an anti-communist agenda that masked a true massacre of the indigenous population. Once again, the avoidance of direct description of violence is remarkable: "el ritual era el mismo y los soldados ya estaban acostumbrados". (LIANO, 2005, p. 103).

By leading the reader to the core of conflict through the experience of the protagonist, in this scene Liano priviledges the point of view of the executioner, thus turning over the traditional vision of the detective who used to embody the good and to persecute evil. Liano shows an infernal vision of the jungle focusing the narrative on two clarifying elements of violence: blood and fire. These elements are transformed into metonyms of the brutality of human sacrifice, although they are also assessed by García's, where the circumstances are naturalised and violence is disregarded.

In this first fragment, the narrator describes by using diminutives ("escuelita") and stresses the Lieutenant's reflection about the amount of blood a body contains:

Los kaibiles se enfurecían al ver la sangre. La gente gritaba y eso a ellos más bravos los ponía. Separaron hombres de mujeres. A unos los metieron en una casita, que servía de escuela y juzgado. A las otras, en una iglesia protestante. Luego, los mataron a todos. Con arma blanca, para no desperdiciar plomo. Había un detalle que siempre llamaba la atención al Teniente García: la cantidad de sangre que contiene un cuerpo. Litros y litros. Al final, en la escuelita, se había formado una poza.

Cuando no quedó nadie vivo, le prendieron fuego a la aldea. Cuando los guerrilleros llegaran, debían darse cuenta de que habían perdido una base. (...) Rápido prendía fuego la madera. Las láminas se encartuchaban y caían ruidosamente en medio del chisperío y el humo negro. La pestilencia era insoportable. Algunas gallinas pasaban corriendo con las plumas empapadas en sangre. El escándalo del incendio se sobreponía al ruido natural de la selva. (LIANO, 2005, p. 104).

In the last example, the guerrillas trapped under flames provoked by the napalm that the military helicopter uses as a repressive measure:

A García todo eso le pareció como un sueño. La cabeza le daba vueltas. Cuando estuvieron sobre el lugar del ataque, dejaron caer las bombas. Era napalm. No es que el bosque se incendiara. Era como si fuego líquido hubiera caído del cielo.

Por varios kilómetros a la redonda quemaron toda la selva. La noche se iluminaba y el infierno fuera poco en comparación con el calor que venía de abajo. "Estos cabrones ya se hicieron chicharrón", le gritó el coronel. Por lejos que hubieran ido los guerrilleros, el incendio los alcanzaría de seguro. García ni se alegró. Sólo sacó el pescuezo y vomitó de cansancio. (LIANO, 2005, p. 109-110). 
In this case, the local language that Liano uses throughout the novel comes out ("Estos cabrones ya se hicieron chicharrón”). José Mejía (2007) states that the insertion of native vocabulary naturalises the genre in relation to its respective social realities. This point gives vividness to the narration and brings informal speech of the different regions into high culture. The autochthonous lexicon is closely linked to the intimacy of the characters and the plot, "Liano pone en escena lo común y corriente: objetos, fenómenos y situaciones de la vida cotidiana, a los que no solemos concederles una naturaleza digna de la literatura” (MEJÍA, 2007, p. 48).

The subversión of the plot

El Hombre de Montserrat presents the traditional enigma of the detective novels through its first-person narrator, Lieutenant García. Traditionally, the mystery is solved in the outcome of the plot by replying to questions such as: "Who is the dead man?", "Who murdered him?", "Why was he killed?" Nonetheless, as it is usual from the crime fiction of the recent decades, in this novel, action predominates over mystery (LAORDEN, 2015, p. 154), and as such finding a solution for the enigma is secondary to stories that affect the main character's life and that have to do with the influence of the violent historical conflict. The body on the road to Montserrat colony is the trigger for an action whose ultimate goal is not the search for the murderer and the request for justice. It seems difficult that poetic justice, so common of other perspectives of this genre, could work in a context where excessive violence prevails.

If the canonical texts by Raymond Chandler targeted the social and economic corruption of Los Angeles, the action in El Hombre de Montserrat aims to recreate an environment of political corruption in the situation of a fierce violent conflict. Dante Liano wrote this novel at the end of the 80's, when the conflict was still incomplete. The jungle was transformed into an extermination camp during the Civil War period and the city of Guatemala became a war area with military rules. The intelligence services were intervened by the United States Army, the government corruption had reached the highest command levels, and mass media had become servile and yellowish. Dante Liano stretches the parameters of the realistic crime fiction in El Hombre de Montserrat in order to adapt it to an armed conflict that at least in symbolic terms was coming to an end in the nineties.

The planning of the story differs from the traditional model based on the clash between protagonist and antagonist. Usually, detective and murderer connect their destinies from an unresolved crime that is the force that generates the plot. Then, the enigma is solved and the guilty is punished. 
Finally, the struggle between good and evil is resolved with poetic justice. As has been pointed out, El hombre de Montserrat presents the mystery of the novel based on an unnamed body that the protagonist finds on his way to work. However, in the context of the 80's and the 90's in Guatemala, the notions of good and evil had been disfigured by the dictatorship of violence.

The presence of the body on the road is appreciated naturally by the protagonist, as a result of his participation in the horrors of war. Lieutenant García stops his Ford Galaxy next to a body on the road. He then turns the body and confirms his previous instict: the unnamed man had been killed in cold blood with a gun:

Se había acercado al cuerpo y confirmó su corazonada.

Alguien le había descargado la tolva, al infeliz, con pésima puntería y una gran suerte. Sólo uno de los tiros parecía mortal, el de la cabeza. De seguro se habían pegado y luego el asesino comenzó a disparar. O, tal vez, el primer tiro fue el mortal y después, de la pura cólera, le descargó la pistola.

"A mí que me importa", pensó García y se dio la vuelta. (LIANO, 2005, p. 12).

At that moment, some judicial police officers arrive and gun point at the Lieutenant. García clarifies the misunderstanding by showing his military credentials, his documentation and his weapon, and manages to arrive at his workplace with a strange feeling. At the office, he remembers: " $;$ Si yo a ese pisado lo conozco! -exclamó, recordándose del muerto” (LIANO, 2005, p. 14), and he presents the mystery that should be revealed at the end of the novel.

Strictly speaking, the plot is unravelled at the end of the narrative, but it does so in a chapter that the author calls "Epilogue". Dante Liano writes an informative post-scriptum to clarify the murder. However, the reader had already forgotten about the body because the action of the novel had changed along the way of the murder investigation.

The common enquiries of the genre are parodied in the constant confusions of the improvised detective. In the end, the reader knows the name of the dead man, Marcos Barnoya, a modest fraudster and friend of his wife's brothers, who was involved in the death of one of them. In the war setting of novel, a dead man with that profile could not have become the protagonist of the plot. Therefore, the story progressively focuses on Lieutenant García's failed investigations. The different events that affect García along the story make him to forget the mystery behind the man of Montserrat.

In this point, José Mejía underlines the light outcome of the mystery:

En efecto, las etapas en la solución del enigma no constituyen en esta obra una progresión, sino otras tantas versiones contradictorias, creídas por el investigador, y por el lector, que no dispone de indicios suficientes para 
determinar su carácter erróneo, hasta que son desautorizadas por nuevas revelaciones de una historia intrincada. La investigación, en lugar de ir resolviendo, parece más bien ir creando el enigma que se le propone al lector. Nada ilustra mejor esto último que el hecho de dejar la solución definitiva para el epílogo, cuando ya no provoca en el protagonista verdadero interés, sino mera curiosidad. El conflicto entre el teniente García y el sistema al que sirve, verdadero móvil de la novela, ha tenido ya su clímax y su desenlace en el quinto y último capítulo, cuando la jerarquía militar castiga al personaje enviándolo a combatir a las guerrillas en el área rural. (MEJÍA, 2007, p. 48).

Mackenbach and Ortiz (2008) also recognise the decentralisation of the plot as Lieutenant García's movements advance and highlight the parodic formula of conflict resolution as one of the outstanding modulations of the genre:

El hombre de Montserrat (1994) del guatemalteco Dante Liano se inicia con el hallazgo que el protagonista, Carlos García, un militar especializado en la lucha contrainsurgente, hace de un cuerpo a orillas de la calle. A partir de este momento, García se obstina por conocer la identidad del muerto, situación que lo llevará por una serie de pesquisas que no resultan en revelaciones ni en respuestas a su curiosidad, sino en una espiral de violencia que afectará su vida. (MACKENBACH y ORTIZ, 2008, p. 91).

Compared to the canonical new detective fiction, the outcome of the plot is resolved by the curiosity of the protagonist, rather than by the appeal of the narrative. Lieutenant García asks about the outcome of the case on his return from the jungle, thus revealing the missing data to the reader. Hence, the initial phrase of the plot becomes premonitory: "A mí que me importa" (LIANO, 2005, p. 12).

Lieutenant García carries out some unsuccessful and misleading investigations, and is the last one to learn about the truth, as well as the reader is. His failure is also the failure of a detective plot that cannot matter in the context of an endless war that the country was living at that moment. In this manner, García discovers the story and realises the narrative crux. $\mathrm{He}$ says devastated: "De toda la historia lo único cierto era la muerte, el exilio y la selva”. (LIANO, 2005, p. 117).

\section{Lieutenant García, caricature of an improvised detective}

Another decisive aspect in the subversion of the crime genre in El hombre de Montserrat is related to the definition of the character who generates the story. As we have already outlined, Lieutenant García is a kaibil destined to the Intelligence Corps of the Army in charge of locating guerrilla hideouts in 
Guatemala City. The choice of the character insists on the caricature of the narrative because in this case, the main protagonist is an active agent of the state's repression. García is a military officer who is introduced as a mediocre man with a professional and family routine. At the end of the story, this image gives way to a man of action posted to the jungle. Over the conflict, he suffers the miseries of the war and meets a woman with whom he has an affair before going back to the city.

Dante Liano gives García certain sensitivity that modulates his personality throughout the story and shows an ironic distancing from the conflict (remember the considerations by Beatriz Cortez [2000] on the aesthetics of cynicism) reflected mainly on the relationship with his superiors and his reactions to terror scenes that he lives personally. In this regard, it is interesting to recall the outline of the personality of Lieutenant García that Mackenbach and Ortiz (2008) suggest:

Su posición con respecto a la guerra de la cual es testigo, provoca en él una contradicción que oscila entre los efectos psicológicos y traumáticos que implica ver el horror, "García pensó que le iban a hacer falta muchas borracheras para borrarse de la memoria lo que estaba viendo" (LIANO, 2005, p. 64) y el sentido de pertenencia que le otorga el ejército, es decir, formar parte del horror: "No sabemos lo que es un ideal. Pero no vamos a perder la guerra, Tono. Ninguna guerrilla le puede al Ejército Nacional: porque estamos dispuestos a todo. [...] Esa es nuestra ventaja: que no tenemos ideales. Para nosotros solo existe la guerra" (LIANO, 2005, p. 115).

Esta novela muestra la figura de un militar/verdugo que es expuesto tanto en su fracaso como en su criminalidad, un personaje a través del cual se transparentan las pugnas éticas y la violencia de su entorno social. Al final será el desarrollo y las implicaciones que el proceso de las indagaciones tiene, el punto de quiebre a través del cual se excavan los crímenes de la represión. (MACKENBACH y ORTIZ, 2008, p. 91).

The narrator presents the facts with a perspective shift that does not allow the reader to empathise with the main character, something unusual in this type of novels. Lieutenant García does not fight against state corruption and violence because he is part of them. Dante Liano does not configure a hero, not even an anti-hero, but an executioner who accidentally gets involved in a family story with murders that he solves with bribery to high state officials. Like a leading actor, Lieutenant García does not have an antagonist in the novel. His own figure would agglutinate with the occasional detective and the perpetual murderer of the institution to which he belongs. At that historical time when military violence populated the streets and forests of the country, nobody in the story cares about Barnoya’s murderer. Consequently, 
García becomes a puppet of a corruption that leads him to feel unsuccessful at the end of the story.

The sensitivity of the executioner can be recovered by the reader from the recurrent resource of the protagonist's dreams. At first, those dreams describe a sense of freedom on a football field, far from war, however, the atrocities of war start to appear progressively and unconsciously make him feel guilty. There are two moments in the novel in which Lieutenant García shows heroic connotations. First, in an outburst to save his brother-in-law by taking him to the Mexican border to free him from the murder charge, and second, in the final recognition of his failure.

Lieutenant García expresses his lack of success by means of an unusual sadness that stands as a cliché of the military executioner. There are two important scenes that portray this idea, and both are associated with metaphors referring to the music of bolero. The first, in chapter 5 , when in a jungle dawn he is able to observe around him, see the suffering and feel pity for the soldiers:

Ahora se había despertado, anegado de tristeza. Oyó la respiración pesada, los ronquidos de los soldados desparpajados en la maleza. Le dieron lástima. Tuvo lástima de sí mismo, también, la misma lástima que sentía en las cantinas cuando de la rockola salía alguna canción ranchera. Era inexpresable, llegaba casi hasta las lágrimas y se complacía en sentirla.

Se sintió fracasado. Todos bien colocados, con altos puestos, con buenos negocios. Sólo él, sólo él. "Sopenco", se recriminó. Y se odió a sí mismo. "Fuera gringo, fuera otra cosa”, pensó y se rió. (LIANO, 2005, p. 101-102).

The second, in the epilogue, when he knows the outcome of the plot and looks at it from a perspective that allows him to verify the meaning of the experience he has lived. All his effort had not served to discover the entanglement in which he had been immersed. Neither his military influence in the intelligence office had not worked, nor his power as the head of the household:

Cuando se montó en el carro, el Teniente Carlos García se puso sentimental. Sintió que había fracasado en la vida. La radio transmitía boleros y durante el camino hacia su casa, no pudo quitarse de encima ese pensamiento. Todo lo que había hecho estaba equivocado. Y la equivocación le iba a durar toda la vida. (LIANO, 2005, p. 118).

Finally, García's failure is also a decisive feature of the subversion of the canonical character of the crime fiction, who usually accomplishes its purpose, in a more or less successful manner, as Mackenbach and Ortiz (2008) pointed out in their study: 
A su vez es una parodia de la fórmula clásica de la novela policial: todas las pesquisas de García fracasan y acentúan el absurdo y la pérdida del estatus de superioridad que supone pertenecer al ejército. A pesar de trabajar en el departamento de inteligencia militar, nunca da con la identidad del fallecido, mientras que los demás -ejército, policía judicial y su propia familia-, conocen las respuestas y las ocultan. (MACKENBACH y ORTIZ, 2008, p. 91).

\section{Demystification of History}

To conclude this essay, it is important to expose some arguments regarding the demystification of history that the use of the caricature proposes in El Hombre de Montserrat. The subversion of the typical crime novel throughout parody works as means to rewrite the recent history of the armed conflict that Dante Liano raises in the story. Again, this aspect links the crime novel with paradigmatic strategies of the new historical novel, which in the last decades of the $20^{\text {th }}$ century approached the great events of the Latin American history with that same ironic distancing (e.g. the treatment of Christopher Columbus in El Arpa y la Sombra by Alejo Carpentier, or the caricatured figurations of the dictators and Simón Bolívar's by the Boom writers).

Dante Liano often uses parody to caricature the period in El Hombre de Montserrat. The perpetuation of violence and the erosion of the strategies of testimonial narrative demanded new narrative proposals. Thus, the caricature develops a fresco that shows a chaotic city, governed by the disputes of power between the military and judicial police in the search for rebellious houses. The army described in El Hombre de Montserrat through the characters in the novel defines an abusive, incompetent institution, lost in an anticommunist battle handled by the United States. Surrounded by a spiral of violence, the protagonists no longer know what their roles are: "No sabemos lo que es un ideal. Pero no vamos a perder la guerra, Tono. Ninguna guerrilla le puede al Ejército Nacional: porque estamos dispuestos a todo. [...] Esa es nuestra ventaja: que no tenemos ideales. Para nosotros solo existe la guerra" (LIANO, 2005, p. 92).

The institutional situation of the country is fragile. On the one hand, the military president has to constantly address the people on the television, while on the other, the judicial police officers ("los orejas") do not share information with the Army, solve cases based on lies or false accusations, and lead the war on their own with controls throughout the country. Meanwhile, the officials of the Art Museum loiter, and the media seeks the morbid live broadcast of the clashes. In this context of corruption and violence, Dante Liano configures several interesting scenes in which the protagonists are caricatured. The demystification of history through caricature is masterfully 
articulated in the scene in which the reader attends live, through a television camera, to the capture of a guerrilla house, thus defocusing the narrator:

Aquí, Canal Uno, el Canal de los Grandes Espectáculos y su noticiero Qué Mundo, en donde se produce la noticia, transmitiendo en directo para el pueblo de Guatemala y teniendo delante de nuestras cámaras, por una cortesía del Banco Inmobiliario y bajo el patrocinio de Cerveza Gallo, la cerveza de todos los guatemaltecos, al general Daniel Vargas, comandante de la base Mariscal Zavala, en el propio sitio de los acontecimientos... (LIANO, 2005, p. 44).

The narrative of an extreme violence scene from the camera of an unscrupulous journalist works as a mechanism to show the conflict from the point of view of the oblique violence and cynicism we had referred to in the theoretical framework. While the journalist's voice retransmits the massacre next to the commanding officer, we can hear the name of the sponsors (a real estate agency and a beer -defining characteristics of the general?). Moreover, the reporter interviews the leader of the military officers while the students' houses are being assaulted. The general warns the Guatemalans of the media assault on a supposed guerrilla house, justified in the communist persecution that Lieutenant García also remembers after the voice of his instructor ("El buen médico extirpa el órgano infectado para que el cuerpo sano pueda vivir", decía el instructor del Infierno Kaibil. "Nosotros somos los cirujanos de este país. Y si nosotros no se lo hacemos a ellos, ellos nos lo harán a nosotros. Así son los comunistas. ¡O ellos o nosotros!”. (LIANO, 2005, p. 104) before proceeding to the unequal exchange of shots that destroys the occupied house. The scene combines the dialogue between the military, accompanied by the American advisers, and the voice of the journalist, who provides a parodic note in the final representation of the brutal violence with which they murder a small number of guerrilla fighters. This fragment perfectly shows the overlapping of parody and caricature in the narrative as a resource for the writing of tragedy:

-... la casa ha quedado reducida a escombros, pero los delincuentes subversivos no se rinden. Este es Canal Uno, transmitiendo en directa y a todo color, por una cortesía de los amables patrocinadores... atención, atención, ahora un grupo de soldados... un grupo de soldados, espero que ustedes puedan verlos a través de las cámaras del Noticiero Qué Mundo, siempre en el lugar donde se produce la noticia, que ustedes estén viendo... los soldados tratan de entrar pero otra vez son... otra vez, disparan desde la casa... están disparando... pueden ustedes ver... que retroceden... retroceden... un momento, me llaman de los estudios, parece que hay información de última hora... un momento, por favor, pedimos a los estudios no interrumpir la transmisión en vivo... informamos, en vivo y a todo color, informamos a los padres de los 
estudiantes de las universidades vecinas que todos... que todos están sanos y salvos... repetimos: sanos y salvos... por una cortesía... sanos y salvos... (LIANO, 2005, p. 52).

Through scenes like this, Dante Liano rehearses the rewriting of a history of violence in Guatemala under the label of the crime fiction, and he continues the tradition of the Latin American writer to become an interlocutor between the official truth and the drama of events. El Hombre de Montserrat modulates a "realidad que destruye nuevamente a la ficción" (PACHECO, 2000, p. 66) subverting a genre perfectly adapted to fit the aesthetic needs of a period in which the distancing and caricature of conflict turned into the first step to reconstruct the memory of pain. As Primo Levi writes in the novel opening:

Il mare di dolore, passato e presente, ci circondava, ed il suo livello è salito di anno in anno fino quasi a sommergerci. Era inutile chiudere gli occhi o volgergli le spalle, perché era tutto intorno, in ogni direzione fino all'orizzonte. Non ci era possibile, né abbiamo voluto, essere isole. (LIANO, 2005, p. 9).

\section{References}

ACEITUNO, Luis. "Dante Liano: memorias de la guerra sucia". Liano, Dante. $E l$ hombre de Montserrat. Guatemala: Editorial Piedra Santa, 2005.

ACEVEDO LEAL, Anabella. "La estética de la violencia: Deconstrucciones de una identidad fragmentada". Temas centrales. Primer simposio centroamericano de prácticas artísticas y posibilidades curatoriales contemporáneas. San José: TEOR/ ética-Gate Foundation, 2000: 98-108.

BARRIENTOS, Dante. "Les jeux de mise en abyme dans El hombre de Montserrat (1996) de Dante Liano". Cahiers d'etudes romances, 9, 2003: 133-146.

COELLO, Emiliano. "Variantes del género negro en la novela centroamericana actual (1994-2006)", Itsmo, 17, 2008. Recuperado de http://istmo.denison.edu/ n17/proyectos/coello.html

CORTEZ, Beatriz. "Estética del cinismo: la ficción centroamericana de posguerra". V Congreso Centroamericano de Historia, San Salvador, 2000.

Grinberg, Valeria. "La est/ética de la guerra en El hombre de Montserrat de Dante Liano". Centroamericana, 17, 2009: 21-34. 
JASTRZĘBSKA, Adriana Sara. "Fuera del tiempo y del mundo: literaturas centroamericanas actuales frente a su historia reciente: Horacio Castellanos Moya”. Romanica Silesiana, 6, 2011:321-341.

JUAN PENALVA, Joaquín. "De cómo el roman fusion llego a serlo: prehistoria literária de uma nueva historia narrativa". Anales de literatura española. 17, 2004: 89-106.

LAORDEN, María Teresa. "Ni Marlowe ni Sherlock. Violencia y novela policíaca en tres ejemplos centroamericanos". Philobiblion, 1, 2015: 153-164.

LIANO, Dante. "La narrativa de la Violencia”. Visión crítica de la literatura guatemalteca. Guatemala: Ed. Universitaria, 1997: 259-271.

LIANO, Dante. El hombre de Montserrat. Barcelona: Roca editorial, 2005.

MACKENBACH, Werner y Ortiz, Alexandra. "Deformaciones: violencia y narrativa en Centroamérica”. Iberoamericana, VIII, 32, 2008: 81-97.

MARTÍN, Alex y SÁNCHEZ, Javier. "Una mirada al neopolicial latinoamericano: Mempo Giardinelli, Leonardo Padura y Paco Ignacio Taibo II”. Anales de Literatura Hispanoamericana, 36, 2007: 49-58.

MEJÍA, José. "La metáfora como buena conductora de mundo en El hombre de Montserrat". Centroamericana, 12, 2007: 43-65.

NOGUEROL, Francisca. "Neopolicial latinoamericano: el triunfo del asesino". Ciberletras: Revista de critica literaria y de cultura, 15, 2006. Recuperado de http://www.lehman.edu/faculty/guinazu/ciberletras/v15/noguerol.html

ORTIZ, Alexandra. "Literatura y violencia: para una lectura de Horacio Castellanos Moya”. Centroamericana, 12, 2007a: 85-99.

ORTIZ, Alexandra. "Las batallas de la memoria: La novela centroamericana como lugar de sobrevivencia". Revista Estudios Universidad de Costa Rica, 20, 2007b: 285-293.

PACHECO, José Emilio. Tarde o temprano. México: FCE, 2000.

RAMÍREZ, Alfredo, Marínez, Lino, Hurtado, Saúl y Melchor, Guadalupe. "Ética y guerra en relatos sobre violencia política en Guatemala (19601996). Cuadernos de Intercambio sobre Centroamérica y el Caribe, 14, 1, 2007: 23-49.

SEOANE, Mercedes Elena. "El hombre de Montserrat de Dante Liano". O Itsmo, 25/09/2014. Recuperado de https://oistmo.com/2014/09/25/analiseen-el-cruce-entre-el-policial-y-la-denuncia-el-hombre-de-montserratde-dante-liano/ 
SKLODOWSKA, Elzibeta. La parodia en la nueva novela hispanoamericana (1960-1985). Amsterdam: John Benjamins Publisihing, 1991.

TODOROV, Tzevan. "Tipolología de la novela policial”. Link, Daniel (comp.). El juego de los cautos. La literatura policial: de Poe al caso Giubileo. Buenos Aires: La Marca Editora, 1992: 46-51.

TOLEDO, Aída. "El hombre de Montserrat de Dante Liano: trasgresión paródica de la fórmula de la novela negra". Vocación de herejes: Reflexiones sobre la literatura guatemalteca contemporánea. Guatemala: Editorial Cultura-Academia Editores, 2002: 90-103.

VALERO, Eva. Lima en la tradición literaria de Perú. De la leyenda urbana a la disolución del mito, Lleida: Universitat de Lleida, 2000.

Víctor Manuel Sanchis Amat é doutor em estudos literários pela Universidade de Alicante (Espanha). Ele faz parte da Unidade de Pesquisa "Recuperaçôes do mundo pré-colombiano e colonial na literatura latino-americana do século XX", dirigido pelos pesquisadores José Carlos Rovira e Carmen Alemany, da Universidade de Alicante. Colabora no comitê editorial da revista America sem nome e faz parte do grupo de pesquisa Didática de idiomas e literatura da Universidade Católica de San Antonio de Murcia. Publicou o ensaio Francisco Cervantes de Salazar, un humanista en la Nueva España del siglo XVI (México, UNAM, 2016) e colaborou na edição do livro de ensaios Raúl Zurita: alegoría de la desolación y la esperanza (Madrid, Visor 2016) em conjunto com os pesquisadores Carmen Alemany e Eva Valero. E-mail: victor.sanchis@ua.es 